\title{
THE LANGUAGE OF CHRISTIAN ETHICS. A DEFINITION OF ETHICAL NOTIONS AS ILLUSTRATED BY THE CONCEPT OF TADEUSZ ŚLIPKO
}

\begin{abstract}
The reflection that accompanies Christian ethics is concerned with its meaning and originality as seen against the background of various interpretations of morality. It usually includes questions about the characteristic subject matter of its inquiries, assumptions, methods, or inspirations. From the point of view of the considerations undertaken in this article, such reflection should also include the language employed by Christian ethics. In particular, this paper considers the following issues: (1) whether Christian ethics has its specific language; (2) whether it introduces new notions, or assigns specific meanings to notions already present in ethics; and (3) how ethical notions are defined in Christian ethics. These questions are addressed with reference to the philosophical system of Tadeusz Ślipko, one of the most outstanding Polish representatives of Christian ethics.
\end{abstract}

Keywords: Christian ethics; ethical notions; language; Tadeusz Ślipko

1. Introduction. 2. Christian ethical notions. 3. Defining ethical notions in Christian ethics.

4. Conclusion.

\section{INTRODUCTION}

Christian ethics has always been concerned with questions about its status: Is there an ethics that can be called Christian? And if so, what determines the Christian nature of ethics? Reflection on the specific nature and meaning of Christian ethics includes questions about the characteristic subject matter of its inquiries, assumptions, methods, sources and inspirations. It is usually emphasized that 
an ethics of Christian orientation ${ }^{1}$ is based on an Aristotelian and Thomist picture of the world, in terms of metaphysics, epistemology and anthropology. Within this framework the most important category is that of substance, which is also used to describe man understood as a potential being, capable of intentional action aimed at achieving good. Such action, according to Christian thinkers, is subject to a deontological qualification in accordance with an objective system of norms and principles which derive their immanent substantiation from human nature, as well as to a transcendental qualification in terms of the divine origin morality (Duchliński 2016, 91). Against the background of today's prevailing naturalism and cognitivism, the specific nature and novelty of Christian ethics results from a substantial and theistic view of the world. Man's naturalistic reduction to his physical brain cannot be reconciled with the most important postulate of Christian ethics, which says that man is a personal being.

A thorough examination of originality of Christian ethics and the issues related to its assumptions and contents should, in my opinion, also include the specific nature of its language. These areas are interdependent: problems discussed by ethicists require a suitable language, and the language proper to Christian ethics affects the content of the problems it investigates. The cognitivist revolution, which has contributed to a significant redefinition of many traditional interpretations related to the phenomenon of morality, rejected key notions which are part of the assumptions made by Christian ethics, most notably that of substance, person, and nature (Duchliński 2016, 73). In this context, the questions that need to be asked are concerned with: (1) whether Christian ethics has its specific

1 It should be noted that there is not a single version of Christian ethics; on the contrary there are many different interpretations of Christian moral philosophy: Thomist, phenomenological, existential, and hermeneutical. They point to different grounds for a Christian interpretation of ethics, suggest its various functions, and refer to different notions and moral categories (Podrez 2016, 98-101). 
language; (2) whether it introduces new notions or assigns specific meanings to notions already present in ethics; and (3) how normative notions are defined in Christian ethics. Our guide in looking for answers to these questions will be Tadeusz Ślipko, one of the most outstanding Polish representatives of Christian ethics ${ }^{2}$ - the author of the only comprehensive model of Christian ethics to have been developed in Poland.

At the beginning of his An Outline of General Ethics, Ślipko emphasizes that this is "an introduction to the secrets of "Christian ethics», or "Christian philosophy of morality»" (Ślipko 2002, 7). The peculiarity of Christian ethics, as Ślipko claims, is determined by the fact that it is theistic, spiritualistic and objectivistic. The Christian ethics practiced by Ślipko is based on fundamental assumptions borrowed from the Thomist system, but also draws from non-Thomist sources. This approach develops a stand different from the traditional Thomist position on certain issues. The main focus of ethical research understood in this way is morality, which consists in specific judgments, convictions, intuitions and moral commands, as well as experiences of values, obligations and conscience that emerge in our moral consciousness. Reflecting on moral phenomena, ethics carries out a philosophical analysis, i.e. discovers their internal structure

2 "In his scientific work, [Tadeusz Ślipko] investigated systemic approaches to Christian ethics and presented his findings in three extensive studies: An Outline of General Ethics and two volumes of An Outline of Detailed Ethics: Personalist Ethics and Social Ethics. Their originality consists in that the basic presentation of Thomist ethics has been methodologically modified and extended in terms of its subject matter... While remaining faithful to the traditional sources of Thomist ethics, Ślipko performed its original modification and reinterpretation in view of contemporary developments in the socio-political situation and the findings of empirical sciences.... Parallel to his work on a systemic approach to Christian ethics, he investigated detailed moral problems. He is the author of original solutions to the problem of moral substantiation of the defence of secrets. $\mathrm{He}$ also analysed the problem of the death penalty and suicide from an ethical point of view, and developed a sexual ethics; in his latest academic work he also investigated bioethical problems, including the ethics of natural environment" (Podrez, Kobyliński, Duchliński, Rozmarynowska 2019, 13-14). 
in order to define the key concepts, that is, formulate the ethical language appropriate to a given issue (Ślipko 2002, 9, 11, 23, 35, 37). That is why we are discussing ethical, rather than moral concepts. They are the result of ethical analysis, i.e. the attempt to formulate and justify the main theses of a certain ethical position.

\section{CHRISTIAN ETHICAL NOTIONS}

Even a brief reflection on the vocabulary of Christian ethics shows that the notional apparatus it employs includes specific notions employed by Christian accounts of morality, as well as notions in common with other ethical systems. Let me begin by introducing the two notions of Christian origin which I believe to be most important. One of them is neighbor - a term which endows a person with a special meaning, and suggests a particular kind of interpersonal bond. Michał Bardel, in an article devoted to exploring various meanings of otherness in relation to such concepts as the 'other', 'you', the 'second' and 'neighbor' indicates that the specificity of the latter results from the fact that "in biblical tradition, a neighbor is any other person, no matter where they come from or what language they speak" (Bardel 2004, 13). A neighbor - as Rosenzweig wrote in The Star of Redemption - is a deputy, a representative of all people. According to Ślipko, the fact that every man is our neighbor, irrespective of their race, nationality, social standing, or moral viewpoint, results from the equality of all people. We all have "the same psycho-physical nature and the resulting moral personal value". Most importantly, the fact that another man is my neighbor entails moral obligation on my part to approach him in a certain way. Christian ethics claims that there is a moral obligation to love one's neighbors, an obligation which stems from natural law. It is an objective and universal imperative which is "not limited in its normative content (everyone - always - towards everyone)." From the Christian perspective, love is understood as an act of accepting the personal dignity of another 
person, and respecting his or her humanity (Ślipko 2005a, 207-216). The notion of neighbor thus includes not only a descriptive, but also a normative element. Once another person is identified as our neighbor, we have a moral duty to respect them, even if they are our enemies. This way, by introducing the notion of neighbor Christian reflection on morality also determines its normative character and the specific content of ethics.

Another notion rooted in Christianity that contributes to the normative character of ethics is that of mercy, which is expressed in an attitude of compassion, pity and the will to help others. It is a virtue proper to Christian morality (Jedynak 1990,152), which commands that love be extended to everyone. In contemporary ethics, the notion of mercy appears in relation to the problem of guilt, punishment and forgiveness, endowing these terms with a special meaning. Mercy in this context is understood as granting a pardon - due to special considerations which justify the wrongdoer. It is a kind of grace aimed at correcting the injustice of legal provisions or moderating institutional justice (Hołówka 2000). Like in the case of neighbor, the notion of mercy establishes a new normative order. By showing the insufficiency of justice understood as compliance with the law, it introduces a new type of obligation in interpersonal and social relations. An authentic act of grace is expressed in waiving a punishment which is believed to be deserved. It requires recognition of a crime on the one hand, and acknowledgement of special, extenuating circumstances which provide moral justification for waiving the punishment on the other. Thus, grace may be considered a particular type of virtue related to the practice of inflicting punishment - the golden mean between strictness and leniency (Smart 1968; Card 1972). It encompasses the area of interpersonal relations which exceeds both justice and love, and which implies an original ethical orientation which could be called an ethics of mercy.

Aside from the notions Christianity introduces in ethics, there are other notions which it endows with special meaning. Two more 
notions deserve to be mentioned here: person and dignity. I have listed them side by side because in Ślipko's ethics they appear together in the expression personal dignity. The Polish ethicist says that "man is a person, that is, a rational individual..., self-contained, unique and responsible for him or herself... Consequently, a person is an acting subject who is independent and self-existent in the order of incidental beings" (Ślipko 2002, 53). The personal nature of man is visible, above all, in his spiritual rationality, which makes him oriented towards rationally striving towards perfection. A person achieves perfection under the influence of the positive values they actualize. This moral improvement, that is, the fact that man is the maker of his own development, distinguishes him as a person. It also enables him to establish personal relationships with others. The most important of these are love and justice, as they consist in choosing good for the sake of another person. Valuable interpersonal relationships contribute to a person's moral development, so moral excellence can only be achieved together with others. Due to his capacity for improvement, man has a personal dignity which makes him a fundamental moral value (Ślipko 2002, 221-224). Dignity is seen as a personal value, and therefore demands affirmation. The axiological aspect of this claim is linked to the normative one, as dignity is also understood as a norm expressing the imperative to recognize the dignity of every human being, and as such represents the moral basis of an individual's relations with others. Such an interpretation of dignity captures its two dimensions: (1) the metaphysical one dignity as a moral value, and (2) the moral one - dignity as the basis of the proper personal conduct and the rights vested in a person (Podrez 2012, 42-43). Christian ethical reflection thus links three categories: dignity, person, and morality. The way it understands dignity determines its perception of a person; the concept of a person, in turn, determines the moral order: "the human person... constitutes a world of generically specified values and the corresponding world of moral norms for which it provides foundations" (Ślipko 
2005b, 94). In Ślipko's interpretation, morality is a reality which corresponds to the personal condition of man. A person is the source of the objectivization of the moral order. The specificity of the Christian understanding of the notion of a person consists in its ontic character - a substantial notion rather than a relational one. This notion is also used in other ethical accounts, but at least in some of them, unlike the Christian approach, the status of being a person depends on numerous capacities, such as memory or selfawareness (e.g., John Locke, Peter Singer). By contrast, in Christian ethics being a person is ontically rooted in the human nature, and dignity is an inherent quality - non-alienable, non-transferable, and non-gradable. The Christian understanding of a person recognizes the value of everyone individually, acknowledges the human dignity of a human individual. Consequently, it emphasizes the dignity of a person which "points to the unique face of every person which makes them inimitable and incomparable" (Styczeń 2013, 22). Interestingly, the Christian description of a personal being resorts to the language of negation, since it cannot be defined in general terms. A person is beyond the limits of what is accessible to our minds and expressible by our language (Styczeń 2013, 22). We are thus faced with a kind of paradox: the notion of person, which is a central notion in Christian ethics and determines its specific nature, is undefinable - it eludes our ability to give it an adequate linguistic expression. ${ }^{3}$

3 The undefinability of the concept of a person refers to the fact that being a person is not a perceptible, observable property, but appears directly in consciousness. The personal dimension of man is not revealed through knowledge, cognition, observation or description. Personal traits (including the traits Ślipko wrote about: spiritual rationality and ability of self-improvement) are nothing else than manifestations of the personal being, rather than its causes. It is impossible to reduce a person to qualities that are manifested externally. Thanks to these features we can recognize a person, but they do not determine the existence of the person. Identification of a person is not the same as his constitution. 
The notions that the Christian tradition introduces in ethics or that it endows with a specific meaning range from general ethics (e.g. happiness, value, natural law, and conscience) to social ethics (e.g. social justice, state, family, and just war). I have deliberately decided not to analyze them here, in order to move to another issue and employ Ślipko's account to consider: (1) how ethical notions are defined in Christian ethics; (2) whether the definitions of ethical notions are descriptive or include a normative and axiological component; and (3) the relationship between these definitions and the deontological qualifications of deeds.

\section{DEFINING ETHICAL NOTIONS IN CHRISTIAN ETHICS}

By ethical notions I mean notions characterizing moral actions (which can be judged as good/bad or right/wrong in the moral sense, e.g. homicide, falsehood, torture), moral virtues (e.g. courage, moderation), moral values (e.g. justice, tolerance), and moral status (e.g. person). Here I will focus my attention on the first group. Such notions as falsehood, murder, theft, torture, offence, and discrimination refer to actions which we usually judge as morally wrong/prohibited. In view of the fundamental function they perform in ethics, we should ask whether they can be defined descriptively, or whether the definition itself also includes a normative component: whether, for example, the notion of theft only describes an action which consists in taking someone else's property, or whether it also includes a judgment of such action as being morally wrong. The latter alternative is supported by the fact that often similar actions are called and defined differently in ethics (and law).

Let us look at some examples. The first one is related to taking someone's life. Ślipko defines homicide as "a deliberate arrangement of suitable actions and tools in order to endow them with a particular quality so that acting in accordance with that quality is aimed directly at causing a person's death" (Ślipko 2005a, 231). As results, according 
to Ślipko's ethics such an action may be considered murder, homicide, or self-defense. In view of their intended purpose, all of these acts are aimed at destroying someone else's life. Since in Christian ethics life is one of the basic goods and represents a "supreme and inviolable value", an act of directly destroying a man's life is considered to be inherently wrong (Ślipko 2005a, 221). What is the difference between the three instances listed above, then? Murder is an act in which a man directly takes the life of another in result of aggression, revenge, or the intention to rob them. Self-defense ("self-protection," "defending oneself") is a necessary defense, i.e. "it represents the ultimate and only means of defense against actual aggression" (Ślipko 2005a, 232). Homicide, on the other hand, is what happens for example during war. What makes these three instances different is their moral evaluation, or, more precisely, the deontological qualification of the deed which substantiates it. Ślipko writes about a different "normative content" of these acts. Murder is an inherently wrong and prohibited act, that is, an act which can never be morally justified. Homicide may be a morally permissible and justified act, while self-defense is "not wrong" morally, i.e. it is a permissible act. Where does this normative differentiation come from? Ślipko explains that "all acts which are aimed directly against the life of a human being, unless in the case of aggression, are morally wrong and forbidden; and in the case of aggression, even if they are also directly aimed at killing, they are not morally wrong" (Ślipko 2005a, 235). Consequently, killing a man in self-defense is not "inconsistent with the objective moral value of the aggressor's life and does not violate his right". For "this value and this right do not extend as far as the field of aggression... It is a situation subject to moral restriction" (Ślipko 2005a, 235). ${ }^{4}$ The permissibility of killing the enemy in combat results directly from

4 "The scope of the moral value of human life and its corresponding right for such life to be respected by other people does not include the situation of an actual aggression" (Ślipko 2005a, 234). 
the moral justification of participating in a just war. Ślipko argues that the state has a moral personality, along with related fundamental rights, such as the right to independence and < territorial integrity. When such rights are violated, the state has the right to defend itself, and sometimes the only effective means of defense is the use of armed weapons, that is, engaging in military operations. Citizens who are members of the national community are obliged to take action for the common good, which includes the fundamental rights of a state. Therefore, Slipko believes participation in a just war to be a morally justified reaction to a wrong done to a state, which may result in taking the life of its enemies. This result is justified, since it is the consequence of aggression (injustice), and "aggression is an act which places the life of the aggressor outside of the moral right to life and its inviolability" (Ślipko 2005b, 237).

Another example of actions and their consequences which are externally similar, but whose definition and evaluation are different, are euthanasia and assisted dying. In both cases we are dealing with actions which result in a patient's death. Let us, again, consider the difference between these acts. Euthanasia, according to Ślipko, is an act of directly killing a terminally ill person in order to put an end to their suffering (Ślipko 2005a, 111). Assisted dying, on the other hand, consists in administering anesthetics or discontinuing (or not undertaking) resuscitation procedures in the case of a patient who is in agony and dying. In both cases, the activities that are undertaken result in a patient's death, but their "normative content" is entirely different. Euthanasia is a morally wrong act, while assistance to the dying is morally permissible, and sometimes even obligatory. This difference results from the inherent purpose of these two acts. Euthanasia is an act aimed directly at taking the life of a suffering patient. By violating "the principle of moral autonomy and inviolability of man's personal dignity... it stands in opposition to the objective norm which makes it mandatory to preserve life." (Ślipko 2005a, 253-254). Assisted dying, when resuscitation procedures are not undertaken or are discontinued, 
does not consist in causing the patient's death, but in removing an obstacle which hinders the natural process of dying. Similarly, in the case of administering anesthetics, their immediate outcome is not death, but consent to its possible acceleration. The purpose of such activities is to palliate or alleviate suffering, which justifies considering them morally permissible. Ślipko assumes that a doctor's duty and right to treat patients using all means at his or her disposal does not extend to a state of agony and dying (Ślipko 2005a, 258-263). Otherwise, the doctor would be prolonging agony, which is inconsistent with the idea of a dignified death, and therefore immoral. ${ }^{5}$

In this context, it is interesting to note that Ślipko also distinguishes suicide from the sacrifice of one's life (some of its forms, so-called 'occasionally deadly acts'). He claims that the criterion which helps differentiate between them consists in "the way these acts are performed, that is, their dynamic structure" (Ślipko 2009, 348). This refers to the presence or absence of suicidal causality. In the case of sacrificial suicide, the subject performs an act which is directly aimed at causing his or her death. A sacrifice of one's life, on the other hand, consists in "taking action which is not deadly in itself, but which coincides with other factors that pose a risk to the life of the acting person, or that are performed in equally dangerous external conditions" (Ślipko 2009, 348-349). In the latter case, even though the subject takes an immense risk of losing his or her life, he or she does not intentionally cause their own death, which is instead what qualifies a sacrificial act as a case of suicide. What differentiates between these actions, even though they are often identical in their consequences, is the intention and disposition of the will. Depending on whether a subject, while defending a morally significant good

5 "Agony and death... belong to the category of man's existence and person. If the expression dignified »death « is to mean anything, then it is precisely in this context: when there is no more hope of a cure, man should be provided with conditions enabling him to leave this world as properly as possible" (Ślipko 2009, 435). 
(another person, a community, religious beliefs) directly causes his own death or only risks losing his life, he performs actions which belong to entirely different deontological categories. Sacrificial suicide is a morally wrong and prohibited act, while the sacrifice of one's own life is a commendable one.

The above examples show that in Christian ethics we are dealing with a normative definition of ethical notions. Acts which are similar in terms of their external expression and consequences are called and defined differently due to their different moral evaluation, which, let us add, results from the specific circumstances in which these acts are performed and from their different inner purpose. What determines the qualification of an act (and thus the category of that act) are usually external circumstances, such as the time and place of action, the status and role of the acting subject, the object, goal and outcome of the action, and sometimes inner, unperceivable factors, such as intentions, purposes, and motives.

Let us notice, however, that normative definitions may cause problems. If we decide that certain notions contain moral judgments, then when an action judged immoral is morally permissible in an exceptional situation, it should be called differently - for example, we should have notions referring to just theft or justified torture. Most of such actions do not have separate descriptions of such exceptional situations. Christian ethics establishes deontological qualifications for particular types of acts within a particular class, giving them different descriptions and providing them with different definitions. The Christian normative code does not result, however, from the recognition of specific imperatives and prohibitions, but from a particular way of understanding the objects of such norms. A good example may be the way Ślipko understands falsehood. He defines it as formal speech ${ }^{6}$ which is inconsistent with a transferrable

6 Formal speech means utterances which express the speaker's own thoughts (Ślipko 2005a, 348). 
thought of the speaking person. Transferrable knowledge consists in information which is not subject to confidentiality. Thus, the scope of falsehood is limited to transferrable knowledge. Such an understanding of falsehood allows exclusion of certain cases of telling an untruth from the scope of the norm which says do not lie. Refusal to disclose a secret (in a situation of unjust verbal aggression) ${ }^{7}$ is not a lie (not even a just or justified lie), but a different kind of action with a different deontological qualification. Ślipko calls it defensive speech, meaning speech which is inconsistent with the inner belief of the speaker, where the content of that belief is an actual secret. It is a deceptive kind of speech, aimed at misleading the aggressor. Revealing a secret, on the other hand, is not an act of truthfulness, but one of betrayal. This way, by restricting the scope of falsehood to transferrable knowledge Slipko preserves the non-exceptionality of the norm do not lie, while at the same time allowing the refusal to disclose a secret, consisting in the deliberate provision of untrue information (Ślipko 2005a, 348-367). In a situation of aggression, falsehood is not a lie. On the contrary, it becomes an act which is morally just and commendable.

Thus, ethical notions in Christian ethics are normative; aside from a descriptive element, they also contain a deontological component. As a result, acts which are judged differently are also provided with different descriptions and definitions. For example, Ślipko lists three types of lies: harmful, useful, and playful ones. The criterion which allows for their differentiation and imposes this typology is first of all normative. Ślipko points out that "the extent of the moral wrong actualized in acts of lying may differ significantly: from slight moral evil usually present in everyday practice, up to - particularly in the case

7 According to Ślipko, when trying to force a person to reveal a secret, the aggressor disturbs the axiological balance between himself and the one who possesses a secret. In order to restore this balance, in such circumstances it is necessary to exclude falsehood from the moral wrongness of lying. This way, the axiological scope of the virtue of truthfulness becomes restricted (Ślipko 2005a, 367). 
of harmful lies - a serious violation of moral law" (Ślipko 2005a, 354). The Polish ethicist also identifies several "untypical forms of untruth" which he deems morally permissible and therefore different from falsehoods: e.g. enigmatic utterances and polite statements. Thus, he assumes that there are circumstances in which one may use formally untrue words without committing a morally wrong act.

The idea of defining ethical concepts through giving different descriptions of acts that differ in moral judgement is certainly original, but also controversial. According to such an account, for example, what is usually considered a lie ceases to be a lie, gaining a completely different status. In consequence, moral dilemmas and value conflicts, which are permanent elements of life, lose their meaning as illusory, having only psychological rather than ethical support. Ślipko resolves at the linguistic level ethical issues that interest lay people and specialists alike (e.g. Is it sometimes acceptable to lie? Is every murder morally wrong?), thus depriving such issues of their problematic nature.

\section{CONCLUSION}

There are several important conclusions that can be drawn from the preceding discussion, which at the same time provide an answer to the issue singled out in the title of this paper:

1. there are specific ethical notions introduced by the Christian reflection on morality, such as neighbor and mercy;

2. Christian ethics assigns specific meanings to widely employed ethical notions: for example the notion of a person acquires an ontic character, unlike in other ethical system;

3. ethical notions in Christian ethics are normative: aside from a descriptive element, they contain a deontological component. Consequently, acts which are similar in terms of their external expression and consequences are called and defined differently 
due to their different moral evaluation, e. g murder, homicide and self-defense.

Summing up, it is clear that language plays a fundamental role in Christian ethics. It is a carrier of the normative dimension of a man's acts. The deontological qualification of acts and their moral evaluation depend on language. The description and definition of a particular act are directly related to its moral dimension, and result directly from it. In addition to a descriptive dimension, an act includes a normative component which refers to the deontological and axiological status of an act.

\section{BIBLIOGRAPHY}

Bardel, M. (2004). Różne twarze inności [Different Facets of Otherness]. Znak, 56(1), 12-15.

Card, C. (1972). On Mercy. Philosophical Review, 81(2), 182-208.

Duchliński, P., Kobyliński, A., Moń, R., and Podrez, E. (2016). Inspiracje chrześciajńskie w etyce [Christian Inspirations in Ethics]. Kraków: Akademia Ignatianum w Krakowie - Wydawnictwo WAM.

Hołówka, J. (ed.). (2000). Filozofia moralności. Wina, kara, wybaczenie [Philosophy of Morality. Blame, Punishment, Forgiveness]. Warszawa: Fundacja Aletheia.

Jedynak, S. (ed.). (1990). Stownik etyczny [Dictionary of Ethics]. Lublin: Wydawnictwo Uniwersytetu Marii Curie-Skłodowskiej.

Podrez, E. (2012). Godność jako podstawa (aksjologiczno-noramtywna) relacji międzyosobowych w ujęciu księdza Tadeusza Ślipki [Dignity as the basis of interpersonal relations according to Father Tadeusz Ślipko]. Studia Philosophiae Christianae, 48(4), 35-53.

Podrez, E., Kobyliński, A., Duchliński, P., and Rozmarynowska, K. (2019). Tadeusz Ślipko. (Series: Polish Christian Philosophy in the 20th Century). Kraków: Ignatinum University Press.

Smart, A. (1968). Mercy. Philosophy, 166(43), 345-59.

Styczeń, T. (2013). Objawiać osobę [To Reveal a Person]. Lublin: Towarzystwo Naukowe KUL - Instytut Jana Pawła II KUL.

Ślipko, T. (2002). Zarys etyki ogólnej [An Outline of General Etbics]. Kraków: Wydawnictwo WAM. 
Ślipko, T. (2005a). Zarys etyki szczegótowej [An Outline of Detailed Ethics]. Vol. 1. Etyka osobowa [Personalist Ethics]. Kraków: Wydawnictwo WAM.

Ślipko, T. (2005b). Zarys etyki szczegótowej [An Outline of Detailed Ethics]. Vol. 2. Etyka spoteczna [Social Ethics]. Kraków: Wydawnictwo WAM.

Ślipko, T. (2009). Bioetyka. Najważniejsze problemy [Bioethics. Main Problems]. Kraków: Petrus.

\section{KAROLINA ROZMARYNOWSKA}

Uniwersytet Kardynała Stefana Wyszyńskiego w Warszawie, Instytutu Filozofii

(Cardinal Stefan Wyszyński University in Warsaw, Institute of Philosophy, Poland)

ORCID: https://orcid.org/0000-0003-3479-7495

k.rozmarynowska@uksw.edu.pl

DOI: 10.21697/spch.2021.57.A.02

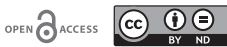

The article is available under the terms of the Creative Commons license (CC BY-ND 4.0 International). Received: 11/02/2021. Reviewed: 24/03/2021. Accepted: 10/05/2021. 